\title{
COLLABORATIVE (PARTNERSHIP) AS A FORM OF "RESTORATIVE JUSTICE" IN CONFLICT RESOLUTION FOREST RESOURCES MANAGEMENT
}

\author{
Agus Surono \\ Faculty of Law, Universitas Al Azhar Indonesia \\ E-mail: surono_uai@yahoo.com
}

\begin{abstract}
Conflict management of forest resources among communities around forest areas often occur in various regions, particularly in some national parks and forest management as Perhutani in Java and Inhutani outside Java. These conflicts indicate the forest resources management has not effectively made a positive impact in improving communities welfare around forest areas. Although the provisions of Article 3 in conjunction with Article 68 of Law No. 41 of 1999 on Forestry, provide the basis for communities around the forest rights of forest areas, but in reality there are still people around forest areas that do not enjoy such rights and it is this which often leads to conflicts in the management of forest resources. In the event of conflict, the solution can be done collaboratively (partnership) which is one form of restorative justice is an alternative dispute resolution (ADR).
\end{abstract}

Keywords: collaborative, conflict, restorative justice, forest resources.

\section{Abstrak}

Konflik pengelolaan sumber daya hutan antara masyarakat sekitar kawasan hutan sering terjadi di berbagai daerah, terutama terjadi di beberapa taman nasional dan pengelolaan hutan oleh Perhutani di Jawa dan Inhutani di luar Jawa. Konflik ini menunjukkan pengelolaan sumber daya hutan masih belum efektif memberikan dampak positif dalam meningkatkan kesejahteraan masyarakat di sekitar kawasan hutan. Meskipun ketentuan Pasal 3 jo Pasal 68 Undang-Undang Nomor 41 Tahun 1999 tentang Kehutanan, memberikan hak bagi masyarakat sekitar kawasan hutan, namun pada kenyataannya masih ada masyarakat di sekitar kawasan hutan yang tidak menikmati hak-hak tersebut dan hal inilah yang sering menyebabkan konflik dalam pengelolaan sumber daya hutan. Dalam hal terjadi konflik, salah satu solusi yang bisa dilakukan adalah melalui penyelesaian secara kolaboratif (partnership) yang merupakan bentuk keadilan restoratif yang dapat dikategorikan sebagai bentuk alternatif penyelesaian sengketa (ADR).

Kata kunci: kolaboratif, konflik, keadilan restoratif, sumber daya hutan.

\section{Introduction}

According to the Ministry of Forestry, extensive tropical forests of Indonesia are approximately \pm 138 million hectares, reflecting wealth of natural tremendously and considered as the lungs of the world which has an important role as a life support system and economic growth. Viewed from its function, the forest area was divided into production forests, protected forests and conservation forests. ${ }^{1}$

Purnawan Dwikora Negara, "Rekonstruksi Kebijakan Pengelolaan Kawasan Konservasi Berbasis Kearifan Lokal Sebagai Kontribusi Menuju Pengelolaan Sumber Daya Alam Yang Indonesia", Jurnal Konstitusi, VoL. IV, No. 2,
Diversity of plants Indonesia was ranked the top five in the world, which has more than 38,000 species, $55 \%$ endemic. The magnitude of the potential for Biological Diversity is certainly very beneficial to the authorized capital of the nation in terms of economic development, primary necessity availability, resources of medicinal plants, means of preservation of cultural values, as well as for the development of science. The existence of the conservation area, are closely related to the presence of local com-

November 2011, Malang: Puskasi FH Universitas Widyagama Malang, page 92. 
munities that have values of local wisdom, but in fact in some other forest areas, they cannot optimally contribute to participation in providing protection and even marginalized, which was seen as a source of conflict. ${ }^{2}$

Conflict management of forest resources is often the case in many areas, both in Kalimantan, Sumatra and other Indonesian regions. Conflict management of forest resources, also often occurs among the forestry, mining, oil and gas, agriculture and other sectors. Only a few cases occur in East Kalimantan, Central Kalimantan, South Kalimantan, West Kalimantan, Jambi, Lampung, South Sumatra, Batam, Seribu Islands and some other parts in Indonesia. ${ }^{3}$

Some forest management-related conflicts, among other, are: ${ }^{4}$ First, Conflicts between indigenous people Sape Labuan Bajo and Kruger National Park (KNP), which is essentially caused by the ban on fishing at zone restrictions imposed unilaterally TNK parties; Second, Conflicts between DIY people and Central Java located around Mount Merapi National Park (TNGM) and TNGM parties, in which people who have lived for generations have ignored their rights; and Third, Conflicts between indigenous people Wakatobi National Park in North Sulawesi Wakatobi archipelago where fishing communities who manage the waters from one generation to another have been barred from entering the zonation area unilaterally by the Wakatobi National Park.

Besides, there are still some cases in other areas which have characteristics similar cases are: the National Park Bromo-Tengger-

2 Rachman Efendi, Indah Bangsawan, and Muhammad Zahrul M, "Kajian Pola-Pola Pemberdayaan Masyarakat Sekitar Hutan Produksi Dalam Mencegah Illegal Logging", Vol. 4 No. 4, December 2007, Jurnal Penelitian Sosial dan Ekonomi Kehutanan, Bogor: Kementerian Lingkung an Hidup dan Kehutanan Republic of Indonesia, page 328-329.

3 Aswandi, Ahmad Suryadin, Cut Rizlani Kholibrina, “Pendekatan Holistik Penanggulangan Illegal Logging dan Degradasi Hutan", Inovasi Media Litbang, Vol. 4 No. 1, 2007, Sumatera Utara: Research and Development of North Sumatra Province, page 43.

4 Dewi Febriani, et.al, "Strategi Implementasi Kebijakan Hutan Tanaman Rakyat di Kabupaten Sorolangun Jambi”, Jurnal Analisis Kebijakan Kehutanan, Vol. 9 No. 2 , 2012, Bogor: Centre for Research and Climate Change and Policy, Research and Development of Forestry, page 91.
Semeru National Park Lore Lindu National Park Togian Islands National Park Rawa Aopa Watomohai, Volcano National Park Hazy, Bunaken National Park, National Park Taka Bonerate, Seribu Islands National Park. Examining the aforementioned examples, the problem characteristics of is the lack of recognition and protection and the rights of indigenous people on forest resource use in which they live. ${ }^{5}$

Conflict management of forest resources also occurs in Perhutani Java and Inhutani other than Java. These conflicts indicate the management of forest resources do not effectively make a positive impact in improving the welfare of communities around the forest areas. Although the provisions of Article 3 in conjunction with Article 68 of Law Number 41 Year 1999 on Forestry provide a basis of community to manage the forest. However, there are still people around forest areas who do not satisfy with such rights and this leads conflicts of the forest resources management. To deal with, the solution can be done collaboratively (partnership) which is one form of restorative justice is an alternative dispute resolution (ADR). ${ }^{6}$

Based on the description, the problems are formulated as follows. First, What are the causes of conflict management of forest resources; Second, What forms of conflict resolution management of forest resources; and Third, How is the completion of a collaborative (partnership) as a form of "restorative justice" in the resolution of conflict management of forest resources.

\section{Discussion}

\footnotetext{
Epi Syahadat \& Subarudi, "Spatial Issues in the Context of Forest Area Plan Revision Provincial Spatial," Jurnal Analisis Kebijakan Kehutanan, Vol. 9 No. 2, 2012, Bogor: Centre for Research and Climate Change and Policy, Research and Development of Forestry, page 139.

6 Satria Astana, Bonar M. Sinaga, et all, "Impact of Macroeconomic Policy and External Factors Against Economic Rate of Deforestation and Forest Degradation of Nature: A Case Study Deforestation To Expanding the Area of Food Crops and Plantation And Industrial Plantation Forest and Degradation Of Natural Forest Concession Area," Jurnal Analisis Kebijakan Kehutanan, Vol. 9 No. 2, 2012, Bogor: Centre for Research and Climate Change and Policy, Research and Development of Forestry, page 167.
} 


\section{Conflict Management on Forest Resource}

Some of the causes of conflict management of forest resources due to factors such as the following: first, there are overlapping regulatory interpretations in the field of forestry. Based on the study the Commission, in the process of designation of forest areas by the Ministry of Forestry has been done unfairly or contrary to the fair principles procedure of the rules of implementation of the Forestry Law. Thus it undermines the legality and legitimacy of $88.2 \%$ of the forest which has not complete set. The absence of legal assurance for map designation of forest areas due to the fact that there are at least four versions different scale forest areas maps, resulting in differences in forest area of 4 to 16 million ha. As a result of the appointment of not performing the inauguration of the forest area, there are 119 potential conflicts in provinces and district division that is partly or entirely located in forest areas. Among others are Nduga, Papua (216. 800 ha) in the protected areas and the district, Raja Ampat (6.0845 million ha) in conservation forests. Related to harmonization spatial forested area, at least there is a potential conflict in the 10 districts/cities expansion in Lampung province and four districts/ cities expansion in South Sulawesi province since they do not propose changes in forest area. ${ }^{7}$

Second, there is a wrong assumption of government and business parties in the forestry sector both public and private about the existence of communities around the forest. People around the forest are often regarded a community who can interfere with the process of forest management which is often positioned as an enemy; the parties must be responsible for violation and environmental destruction. If the forest area is considered as a resource to generate foreign exchange, the forest area should be protected and preserved. The concept of pro-

\footnotetext{
Dian Agung Wicaksono \& Ananda Prima Yurista, "Konservasi Hutan Partisipatif Melalui REDD+ (Studi Kasus Kalimantan Tengah Sebagai Provinsi Percontohan REDD+)" Jurnal Wilayah dan Lingkungan, Vol. 1 No. 2, 2013, Semarang: Laboratory of Regional Development and Environment Management Department of Urban and Regional Planning, Universitas Diponegoro, page 194.
}

tecting and preserving requires a management to apply the standards of protection through regulations that sometimes restrict people's interaction with the forest. ${ }^{8}$

Third, there are different historical conditions in forest management both Java and other parts. Aspects of the scarcity of land on Java Island are the most prominent dimension of the conflict. The battle over infringement dominates the range of conflict management of forest in Java. While outside Java, aspect of land scarcity has not been a major issue of conflict, but customary claims and rights of indigenous management of conflicts which dominantly influence forest management are good for conservation forests and production forests. ${ }^{9}$

In regards to this, there are several other issues related to the management of the national park which are described as follows: ${ }^{10}$ first, illegal logging. Illegal logging also exploits national park area for large diameters of a tree forest can provide. While forest production potentially declines due to intensive exploitation and opposed to legal concession holder. Second, the impact of land utilization changes around the conservation area. It is increasingly prevalent after regional autonomy, where many new provinces and districts expand so it is necessary to rearrange spatial plan to accommodate various interests. Unfortunately, the main consideration changes in land use which are mostly economic interests often ignore aspects of environmental safety and sustainability. Third, illegal pilfering. Pilfering in national parks is done by various way using snares, traps, poison, dogs and guns. A huge market opportunity leads to wildlife pilfering is difficult to remove. Fourth, the issue of boundaries. Dispute over regional

8 Edi Slamet Sumanto, "Social Forestry Development Policy in the Perspective of Conflict Resolution", Jurnal Analisis Kebijakan Kehutanan, Vol. 6 No. 1, April 2009, Kupang: Kupang Forestry Research Institute, page 16.

9 Faiqotul Falah, "Collaborative Management Effectiveness Assessment Kutai National Park", Jurnal Analisis Kebijakan Kehutanan, Vol. 10 No. 1, April 2013, Balikpapan: Technology Research Institute for Natural Resource Conservation, page 41.

10 Iswan Dunggio \& Hendra Gunawan, "Assessing Historical National Park Management Policy in Indonesia", Jurnal Analisis Kebijakan Kehutanan, Vol. 6 No. 1, April 2009, Bogor: Center for Forest and Nature Conservation, page 47-51. 
boundaries with the community is an issue that caught attention lately as a response to the era of regional autonomy since rolled out. ${ }^{11}$ Fourth aforementioned problems is a specific issue of conflict in the management of national parks, in addition to other problems as described above under conflict in the management of forest resources.

\section{Forms of Forest Resource Conflict Resolution}

Resolution of the conflict management of forest resources can be solved through several approaches courts settlement (litigation) and non-court settlement (non-litigation). Settlement through the courts can be done by criminal, civil and state administration. While the out of court settlement can be done through consensus, mediation, and also the settlement of partnerships. Of the two types of conflict resolution approach to the management of the forest resources, taking into account the objective conditions in Indonesian law, settlement out of court which is often known as alternative dispute resolution (ADR) may be appropriate in resolving the conflict management of forest resources.

Conflict resolution outside the court initially emerged from their dissatisfaction with the process of conflict resolution through the court that takes a relatively long time and large cost. In addition, the decision produced by the court often causes dissatisfaction of the parties or there are those who feel as losers. ${ }^{12}$

Development of alternative dispute resolution, such as negotiation, mediation and conciliation is supported by several factors namely: first, established solution in many cultures; second, non-adverse solution; third, allows all dispute-related parties to be included in the negotiations; fourth, a win-win solution. ${ }^{13}$

11 Sri Mamudji, "Mediasi Sebagai Alternatif Penyelesaian Sengketa di Luar Pengadilan", Jurnal Hukum dan Pembangunan, Vol. 3, September 2006, Jakarta: Faculty of Law Universitas Indonesia, page 194-195.

12 Abu Rokhmad, "Tanah Kawasan Hutan dan Resolusinya Dalam Perspektif Fiqh ", Walisongo. Vol. 21. No. 1. May 2013, Semarang: Semarang IAIN Walisongo, page 147.

13 Richard Hill, "Non Adversial Mediation", http:/www. Batnetcom/oikoumene/arbmed3. html. Accessible: September 8, 2016.
There are various forms of dispute resolution outside the court, as it is written Nolan-Haley, "ADR is an umbrella term wich refers generally to alternative to court adjudication of disputes such as negotiation, mediation, arbitration, mini trial and summary jury trial." 14 The purpose of the development of alternative dispute resolution is to provide a forum for the parties to work towards a voluntary agreement in making decisions about the dispute that it faces. Thus the alternative dispute resolution is a potential means to improve relations between the parties to the dispute. Some forms of conflict resolution management of forest resources is carried out through out of court settlement are explained as follows: deliberation and consensus; and mediation.

Conflict resolution (dispute) alternatives have long been used by traditional communities in Indonesia in the context of resolving the dispute between them. Alternative dispute resolution is traditionally considered to be effective and is a tradition that is still preserved in the community. Resolution mechanisms with the consensus agreement reflects the principles of harmony, on merit, the principle of alignment with settlement acceptable to the parties concerned and the people concerned. ${ }^{15}$

Mediation is an extension of the negotiation process if the parties are not able to resolve disputes. They will use a third party to assist them to come an agreement. In mediation, the third party will assist the conflicting parties in implementing values that include legal, sense of justice, religious beliefs, moral and ethical issues. Mediation is a process in which a neutral party agreed upon by the parties of the dispute, to act as a facilitator for the benefit of their

14 Muhammad Yamani, "Strategi Perlindungan Hutan Berbasis Hukum Lokal Di Enam Komunitas Adat Daerah Bengkulu ", Jurnal Hukum lus Quia lustum, Vol. 18 No. 2. April 2011, Yogyakarta: Faculty of Law Universitas Islam Indonesia, page 180.

15 Teguh Hari Santoso, Insan Wijaya, Arief Noor Akhmadi, "Social and Economic Studies Program at Forest Area PHBM Catchment Slopes Roar," Agritrop: Jurnal Ilmu-Ilmu Pertanian, Vol. 7 No. 1, Jember: Faculty of Agriculture, Universitas Jember Muhhamdiyah, page 73. 
negotiations and help them reach a mutual solution." 16

In the mediation process, it must consider the following matters: first, if in a dispute settlement seems stagnant or deadlock between the conflicting parties, the cause shall be found out; second, the background of the institution shall be known in negotiating; third, to keep sustainable in conflict management, there must be a prerequisite before a previous joint management; fourth, in a dispute resolution, negotiation is the first step to do; fifth, a success of the negotiations is indicated if the talks went smoothly and met the needs of the respective interests of the parties; sixth, the mediator's role does not actually specify the correct one but more to the management of a dispute through a pragmatic approach and can be accepted by the parties of the dispute; and seventh, selection step in resolving the conflict to the wider issues must know its strengths.

Collaborative Settlement (Partnership) as a Form of "Restorative Justice" in the Forest Resource Conflict Resolution

In addition to use some settlements of such consensus and mediation in conflicts forest resource management, it can be done through collaborative (partnership) method by the involvement of all stakeholders involved in the conflict of the forest resources. The completion of a collaborative method is the implementation of handling issue in order to help improve the effectiveness of the regional management as well as the parties on the basis of understanding and agreement. ${ }^{17}$

The development of collaborative approaches in Indonesia as known as partnership in Indonesia conceptually and actual practice has been intense debate and study. In Indonesia in

16 Sudi Fahmi, "Problematika Hukum dalam bidang kehutanan", Jurnal Hukum Respublica, Vol. 6 No. 1, Kepulauan Riau: Faculty of Law Universitas Lancang Kuning, page 51.

17 Agnes Wyona, "Penyelesaian Sengketa Lingkungan Hidup Melalui Mediasi Antara Masyarakat dengan Perusahaan di sekitar Kelurahan Bukuan Kecamatan Palaran Kota Samarinda", Jurnal Beraja Niti, Vol. 2 No. 8, 2013, Kalimantan Timur: Faculty of Law Universitas Lambung Mangkurat, page 8 . the early 1990s, collaboration management is better known as a partnership often connoted with inti-plasma management between farmers and plantation firms or model of foster parents between small businesses and large businesses. ${ }^{18}$

Historically, the development of collaborative approaches initially emerged as a response to the demands of new resources, democratic, management which recognizes the huge expansion on the human dimensions of managing choices, uncertainty, the complexity of potential decisions and building understanding, support, optional ownership. ${ }^{19}$

There are three patterns of partnership in a organization as identified by Huxham and Macdonald: first, coordination in which no direct interaction occur among organizations but the organization considers the activities of the other party in its planning; second, cooperation in which the organizations interact to achieve its mission and objectives to be more effective; and third, collaboration where organizations work together to achieve a meta-mission as well as to pursue the mission and objectives of the individual they have. ${ }^{20}$

In the context of natural resource management schemes partnership schemes is known as "joint management/co-management, or collaborative management". Partnership is normally defined as the various responsibilities and/or authority between the government and local resource users in managing certain resource. $^{21}$

The steps of conflict resolution process is taken through intensive assistance to get the completion strategy through collaborative pat-

18 Suporahardjo, 2005, Strategies and Practices Collaboration: An Overview, Bogor: LATIN Library, page 3.

19 Herawan Sauni, "Perilaku Masyarakat dalam Merambah Hutan Lindung Bukit. Raja Mandara di Kecamatan Kedurang Kabupaten Bengkulu Selatan”, Supremasi Hukum: Jurnal Penelitian Hukum, Vol. 11 No. 12006 , Bengkulu: Faculty of Law Universitas Bengkulu, page 59.

20 Andri Santosa, et al, "Status of Community Forestry in Indonesia," Jurnal Kehutanan Masyarakat, Vol. 3 No. 1, 2011, Bogor: Community Forestry Communication Forum, page 12-13.

21 Yusuf Bahtimi Samsudin \& Romain Pirard, "Mediation Conflict To Forest Industry Plant in Indonesia," Brief Info, No. 107, Desember 2014, Bogor: Cifor, page 3-4. 
terns, namely: ${ }^{22}$ first, formulate perceptions and chronologically complete conflict. Complete history of events that became the basis for the analysis of a vision, mission, and to conduct polls among stakeholders. The perspective of each stakeholder is the basis to come up with a joint commitment and seek alternative best solution. Second, introduce the concept of Integrated Rehabilitation concessions as the main solution. At this stage the conservation group is expected to offer the concept of rehabilitation in order to recover and preserve the integrity of the forest area. Third, establish cooperation and collaboration with various parties. Collaboration is needed to oversee the settlement process, sharing the workload, and provide the opportunity for all parties to take the role. More importantly is to foster a sense of shared responsibility and actualize the commitments that have been formed in the previous stage. Fourth, formal legal phase. These steps are taken after the strengthening of the organization in the form of collaborative management deemed strong enough to ensure that all processes and implementation activities to occur properly. Fifth, evaluation and monitoring. Evaluation and monitoring of the activities were carried out at each stage. There is a possibility of emerging alternative other settlement according to the development problems. The final evaluation is needed as a material reflection for further activities.

In accordance with the policy and conservation management strategies in the field of forestry development program of Forest Protection and Nature Conservation and the 3 pillars of conservation is the function of protection, preservation and sustainable use, the necessary support to increase community empowerment and development of conflict resolution mechanisms. Through this activity, it is expected a target and strategy as the result of mutual participatory, collaborative and accountable agreement are implemented in accordance with the commitments. The target and strategy will then be used in problem solving as a whole so that

22 Suporahardjo, et al, Op.cit,, page17-19. the area can be rehabilitated and return to normal function as a conservation area. ${ }^{23}$

Related to the management of forest resources conflicts with collaborative pattern (partnership), there are several rules in Indonesian legislation, namely: ${ }^{24}$ first, Law Number 5 Year 1990 on Conservation of Living Natural Resources and its Ecosystem, as a legal basis allowing the forest resources to be jointly managed to support cultivation and recreation; second, Law Number 41 Year 1999 on Forestry, the implications includes to maintain functions of the national park which is necessary basics consolidation area due to high pressure and that the oil and coal mining operations and settlements within the park is an unlawful activity; third, Law Number 23 Year 2014 on Local Government stated that sub forestry sector is a matter of choice that can be managed by the local administration to participate and collaborate in the management of forest resources in the region; and fourth, Law Number 19 Year 2004 on Natural Reserve Management and Conservation Areas which contains guidelines for the preparation, implementation, monitoring and evaluation in collaborative management of protected areas, involving various stakeholders.

In relation to forest resource management, conflicts may occur between private sector and government, private sector and private sector, public and the private sector and also public and government. Regarding to the parties position involved in the conflict management of forest resources, the community has always been placed as the weak. Therefore, to protect the interests of people who often become victims of the conflict management of forest resources, settlement-based collaborative deliberation can be one of the most effective solution to the conflict by involving all stakeholders

\footnotetext{
23 Marinus Kristiadi Harun \& Hariyanto Dwiprabowo, "Resolution Model of Land Conflicts in Banjar Production Forest Management Unit Model," Jurnal Penelitian Sosial dan Ekonomi Kehutanan, Vol. 11 No. 4 Desember 2014, Bogor: Research and Development Center for Climate Change and Policy, pages 276-277.

24 Ibid., page 278.
} 
involved in the conflict management of forest resources. ${ }^{25}$

Collaborative approach is one models for conflict resolution management on forest resources of restorative justice where all parties related to the conflict settlement involved with the principle of win-win solution. How collaborative settlement (partnership) is a form of settlement of restorative justice that emphasizes the principles of justice based on consensus.

The essence of substantial completion of restorative justice in conflict management of forest resources in many countries is mostly caused by their dissatisfaction with the resolution through the judicial system. Restorative justice in conflict resolution management of forest resources is also intended to protect the interests of local people who have local knowledge in the management of forest resources. ${ }^{26}$

Through a collaborative settlement (partnership), people have an equal opportunity to utilize the forest resources as forest resource management objectives as set out in Article 3 of Law Number 41 Year 1999 on Forestry which states "Forest management shall be aimed at providing maximum prosperity for the people based on justice and sustainability by: first, securing existence of forest at adequate extent and proportional distribution; second, optimizing various forest functions covering conservation, protection, and production functions to attain environmental, social, cultural and economic benefits proportionally and sustainably; third, increasing baring capacity of river sheds; fourth, increasing capability to develop community's capacity and capability on participation, justice, and sustainability basis to create social and economic resilience as well as endurance against impacts of external changes; and fifth, securing distribution of benefits on just and sustainability basis.

Furthermore, Article 68 of Law Number 41 Year 1999, stated that:

\footnotetext{
25 Lilik Mulyadi, 2014, Wajah sistem peradilan pidana anak Indonesia, Bandung: PT. Alumni, page 156.

26 Ibid., page 157.
}

1) The community shall be entitled to enjoy environmental quality the forest produces.

2) Besides right as referred to in paragraph (1), the community can also:

a. Utilize forests and forest products according to the prevailing legislation.

3) The community in and around the forest shall be entitled to compensation against loss of access to surrounding forest as employment opportunity to fulfill their daily need due to forest area designation according to the prevailing legislation.

4) Each person shall be entitled to compensation against loss of their title to land they own due to forest area designation according to the prevailing legislation.

Under the provisions of Article 3 in conjunction with Article 68 of Law Number 41 Year 1999 mentioned above, it can be concluded that if there are conflicts over the management of forest resources, the solution can be done through the completion of a collaborative (partnership) approach which is a form of restorative justice in conflict resolution management of forest resources.

\section{Conclusion}

First, the issues of conflict management of forest resources occur for several reasons: the overlapping interpretation of the regulations in the field of forestry, the notion that one of the government and business entities in the forestry sector both public and private about the existence of the community around forests, their different historical conditions in forest management in Java and outside Java.

Second, that the settlement of the conflict management of forest resources can be resolved through the dispute resolution outside the court. Dispute resolution outside the court, among others, can be done through consensus, mediation and settlement collaborative (partnership).

Third, that the collaborative (partnership) approach is a highly effective conflict resolution for conflicts over the management of 
forest resources. This is due to a balanced cooperation among all stakeholders involved in the conflict management of forest resources. Conflict resolution management of forest resources in a collaborative (partnership) approach is a form of restorative justice that can be developed in conflict resolution management of forest resources.

\section{References}

Aswandi, Ahmad Suryadin. Cut Rizlani Kholibrina. "Pendekatan Holistik Penanggulangan Illegal Logging dan Degradasi Hutan.“ Inovasi Media Litbang. Vol. 4 No. 1. 2007. Sumatera Utara: Research and Development of North Sumatra Province;

Astana, Satria. Bonar M. Sinaga. et all. "Impact of Macroeconomic Policy and External Factors Against Economic Rate of Deforestation and Forest Degradation of $\mathrm{Na}$ ture: A Case Study Deforestation To Expanding the Area of Food Crops and Plantation And Industrial Plantation Forest and Degradation of Natural Forest Concession Area." Jurnal Analisis Kebijakan Kehutanan. Vol. 9 No. 2. 2012. Bogor: Centre for Research and Climate Change and Policy. Research and Development of Forestry;

Dwikora, Purnama. "Reconstruction Policy-based Conservation Area Management As Contribute Towards Local Wisdom Natural Resources Management in Indonesia". Jurnal Konstitusi. VoL. IV No. 2. November 2011. Malang: Puskasi FH Universitas Widyagama Malang;

Dunggio, Iswan and Hendra Gunawan. "Assessing Historical National Park Management Policy in Indonesia". Jurnal Analisis Kebijakan Kehutanan. Vol. 6 No. 1. April 2009. Bogor: Center for Forest and $\mathrm{Na}$ ture Conservation;

Efendi, Rachman. Indah Bangsawan. and Muhammad Zahrul M. "Kajian Pola-Pola Pemberdayaan Masyarakat Sekitar Hutan Produksi Dalam Mencegah Illegal Logging." Jurnal Penelitian Sosial dan Ekonomi Kehutanan. Vol. 4 No. 4. December 2007. Jurnal Penelitian Sosial dan Ekonomi Kehutanan. Bogor: Kementerian Lingkungan Hidup dan Kehutanan Republic of Indonesia;
Febriani, Dewi. Dudung Darusman. et al. "Strategi Implementasi Kebijakan Hutan Tanaman Rakyat di Kabupaten Sorolangun Jambi". Jurnal Analisis Kebijakan Kehutanan. Vol. 9 No. 2. 2012. Bogor: Centre for Research and Climate Change and Policy. Research and Development of Forestry;

Falah, Faiqotul. "Collaborative Management Effectiveness Assessment Kutai National Park". Jurnal Analisis Kebijakan Kehutanan. Vol. 10 No. 1. April 2013. Balikpapan: Technology Research Institute for Natural Resource Conservation.

Fahmi, Sudi. "Problematika Hukum dalam bidang kehutanan." Jurnal Hukum Respublica. Vol. 6 No. 1. Kepulauan Riau: Faculty of Law Universitas Lancang Kuning;

Hill, Richard. "Non Adversial Mediation". access on http:/www.Batnetcom/ oikoumene/ arbmed3. html. Accessible: September 8. 2016;

Harun, Marinus Kristiadi and Hariyanto Dwiprabowo. "Resolution Model of Land Conflicts in Banjar Production Forest Management Unit Model." Jurnal Penelitian Sosial dan Ekonomi Kehutanan. Vol. 11 No. 4 Desember 2014. Bogor: Research and Development Center for Climate Change and Policy;

Mulyadi, Lilik. 2014. Wajah sistem peradilan pidana anak Indonesia. Bandung: PT. Alumni;

Negara, Purnawan Dwikora. "Rekonstruksi Kebijakan Pengelolaan Kawasan Konservasi Berbasis Kearifan Lokal Sebagai Kontribusi Menuju Pengelolaan Sumber Daya Alam Yang Indonesia". Jurnal Konstitusi. VoL. IV No. 2. November 2011. Malang: Puskasi FH Universitas Widyagama Malang;

Raharja, Sunarya. “Indonesian Biodiversity Legal Protection Against Development of Biotechnology." Jurnal Hukum Respublica. Vol. 6 No. 1. Kepulauan Riau: Faculty of Law Universitas Lancang Kuning;

Rokhmad, Abu. "Tanah Kawasan Hutan dan Resolusinya Dalam Perspektif Fiqh". Walisongo. Vol. 21 No. 1. May 2013. Semarang: Semarang IAIN Walisongo;

Suporahardjo, 2005. Strategies and Practices Collaboration: An Overview. Bogor: LATIN Library; 
Sauni, Herawan. "Perilaku Masyarakat dalam Merambah Hutan Lindung Bukit. Raja Ma ndara di Kecamatan Kedurang Kabupaten Bengkulu Selatan". Supremasi Hukum: Jurnal Penelitian Hukum. Vol. 11 No. 1 2006. Bengkulu: Faculty of Law Universitas Bengkulu;

Santosa, Andri. et all. "Status of Community Forestry in Indonesia." Jurnal Kehutanan Masyarakat. Vol. 3 No. 1. Tahun 2011. Bogor: Community Forestry Communication Forum;

Mamudji, Sri. "Mediasi Sebagai Alternatif Penyelesaian Sengketa di Luar Pengadilan". Jurnal Hukum dan Pembangunan. Vol. 3. September 2006. Jakarta: Faculty of Law Universitas Indonesia;

Santoso, Teguh Hari. Insan Wijaya. Arief Noor Akhmadi. "Social and Economic Studies Program at Forest Area PHBM Catchment Slopes Roar." Agritrop: Jurnal Ilmu-Ilmu Pertanian. Vol. 7 No. 1. Jember: Faculty of Agriculture. Universitas Jember Muhhamadiyah;

Samsudin, Yusuf Bahtimi and Romain Pirard. "Mediation Conflict To Forest Industry Plant in Indonesia." Brief Info. No. 107. December 2014. Bogor: Cifor;

Suporahardjo, et al. 2009. Innovation Settlement Forest Resource Management. Bogor: LATIN Library;

Syahadat, Epi and Subarudi. "Spatial Issues in the Context of Forest Area Plan Revision Provincial Spatial." Jurnal Analisis Kebi- jakan Kehutanan. Vol. 9 No. 2. 2012. Bogor: Centre for Research and Climate Change and Policy. Research and Development of Forestry;

Sumanto, Edi Slamet. "Social Forestry Development Policy in the Perspective of Conflict Resolution". Jurnal Analisis Kebijakan Kehutanan. Vol. 6 No. 1. April 2009. Kupang: Kupang Forestry Research Institute;

Wyona, Agnes. "Penyelesaian Sengketa Lingkungan Hidup Melalui Mediasi Antara Masyarakat dengan Perusahaan di sekitar Kelurahan Bukuan Kecamatan Palaran Kota Samarinda". Jurnal Beraja Niti. Vol. 2 No. 8. 2013. Kalimantan Timur: Faculty of Law Universitas Lambung Mangkurat;

Wicaksono, Dian Agung \& Ananda Prima Yurista. "Konservasi Hutan Partisipatif Melalui REDD+ (Studi Kasus Kalimantan Tengah Sebagai Provinsi Percontohan REDD+)". Jurnal Wilayah dan Lingkungan. Vol. 1 No. 2. 2013. Semarang: Laboratory of Regional Development and Environment Management Department of Urban and Regional Planning. Universitas Diponegoro;

Yamani, Muhammad. "Strategi Perlindungan Hutan Berbasis Hukum Lokal Di Enam Komunitas Adat Daerah Bengkulu". Jurnal Hukum lus Quia lustum. Vol. 18 No. 2. April 2011. Yogyakarta: Faculty of Law Universitas Islam Indonesia. 